\title{
DETERMINANTS OF DEVELOPMENT \\ OF THE MUTUAL FUND INDUSTRY. \\ A SOCIO-CULTURAL APPROACH
}

\section{Ingrid-Mihaela Dragotă, Delia Tatu-Cornea, Narcis Tulbure*}

\begin{abstract}
The mutual fund industry has grown considerably in many countries since the 1990s. Its evolution has been explained primarily in terms of its economic and financial determinants. We draw on a dynamic set of measures for socio-cultural values to explain the differential development of mutual funds across the world. Using a sample of 38 countries for the period 1996-2009, we find a positive relation between the perception of happiness and the size of the mutual fund industry. Freedom of choice, a feature of countries that are dominated by individualistic behaviours and values, has a positive impact on the development of the industry. We also explain the positive relation between individuals' preference for private ownership and the development of mutual funds. Moreover, we prove that the industry is larger in developed countries with greater stock market liquidity, with low ratios of remittance inflows to GDP, and in which the industry is older.
\end{abstract}

Keywords: mutual funds, socio-cultural values, financial development

JEL Classification: G23, A13, Z13

\section{Introduction}

The mutual fund industry has grown considerably since the early 1990s and a large body of literature was devoted to explaining its determinants. However, the data show disparities in both the size and the growth rates of this industry that cannot be overlooked ${ }^{1}$. This heterogeneity is the starting point for our research. For the countries in our sample, for the period 1996-2009, the average value of the ratios of net total assets to GDP in the US was

* Ingrid-Mihaela Dragotă, Bucharest University of Economic Studies, Bucharest, Romania (mihaela.dragota@fin.ase.ro); Delia Tatu-Cornea, European Business School Paris, Paris, France (deliacornea@ebs-paris.com); Narcis Tulbure, Bucharest University of Economic Studies, Bucharest, Romania (narcis.tulbure@fin.ase.ro).

This work was supported by Executive Agency for Higher Education, Research, Development and Innovation Funding [project PNII-IDEI, code 1831/2008]. Also, this research was supported by a grant from the CERGE-EI Foundation under a program of the Global Development Network [Regional Research Competition VIII-61]. All opinions expressed are those of the authors and have not been endorsed by CERGE-EI or the GDN, or by the Executive Agency for Higher Education, Research, Development and Innovation Funding.

We are grateful to the participants of the 15th INFER Annual Conference, Orleans, May 29-June 1, 2013 and to the participants of the EBES Conference, Zagreb, October 13-15, 2011 for their valuable input on earlier versions of this paper. The authors wish to thank Victor Dragotă, Alexandru Todea and Andreea Semenescu for their useful comments. We also thank Delia Cataramă for helpful contributions to previous versions of this paper. The remaining errors are ours.

1 The net asset values of mutual funds ranged from US\$235 million for Romania to over US\$ 7 billion for the United States. Net-asset-value-to-GDP ratios ranged from $0.17 \%$ (Romania) to $82.3 \%$ (Australia), with a large dispersion. 
68.13\%, in Japan $10.27 \%$ and in France 56.97\%. What factors explain the differences in the size of this industry between these high-income countries?

Previous works on this topic (e.g. Klapper et al., 2004; Khorana et al., 2005) have focussed specifically on financial, socio-economic, and political aspects as factors that drive the size of mutual funds. Our paper draws on a more comprehensive set of variables and analyses them over a 14-year period ${ }^{2}$. Employing a sample of 38 countries around the world we analyse the cross-sectional differences in the size of national industries using the ratios of net total assets to GDP and of net total assets scaled by the country's population for the period from 1996 to 2009. Our effort contributes to the literature by analysing the influence of socio-cultural values such as happiness, trust, individuals' perception regarding the freedom of choice, the preference for a specific type of ownership (public versus private), and religious affiliation on the development of mutual funds. These values are expected to induce specific consumption, saving, and investment behaviours and can be linked with the characteristics and saving objectives of mutual funds shareholders.

The emerging literature on culture and finance indicates that socio-cultural variables are able to explain many of the choices made by investors as well as a considerable part of the international variability in the development of financial markets and institutions (Breuer and Quinten, 2009; Reuter, 2011). Recent studies have laid the groundwork for the analysis of the relationship between happiness and the development of the mutual fund industry. For example, Guven (2012) prove that happiness can shape both consumption and saving behaviours. Furthermore, economic sociologists have explored the intricate role of morality and religion in the economy (Peifer, 2011, for a review of these subjects). However, few studies have explored the connection between religion, moral values, and mutual funds (Peifer, 2011).

Socio-cultural values seem to be particularly apt at explaining the behaviour of mutual fund investors and the development of the sector as individual investors have become dominant shareholders of mutual funds. This conclusion is based on the periodic surveys conducted in countries with developed markets such as the US and Canada (ICI 2012a, 2012b; IFIC, 2012) and the occasional assessments of emerging markets such as China (Tingchi et al., 2007). The cited studies reveal that most individual investors are middle aged, in good financial condition, with higher education and in respected professions, while the major reason for investing in mutual funds seems to be savings for retirement. They might be the channel through which socio-cultural values manifest their influence on national mutual fund industries.

Reviews of the existing literature (Van Campenhout, 2007) or individual papers (Müller and Weber, 2010; Bailey et al., 2011) reveal how diverse behavioural and demographic criteria influence investors' choice of funds. Consequently, we expect that sociocultural variables work in conjunction with these factors and have an impact on the development of the mutual fund industry especially as the regularly considered economic and financial factors do not explain the full variability in the development of mutual funds around the world. National authorities, practitioners and academics can use cultural values to boost the mutual fund industry in different countries. Both managers of mutual funds and investors may be interested in the influence of socio-cultural variables to determine the

2 Klapper et al. (2004) covered a period of six years, while Khorana et al. (2005) analysed the size of the mutual fund industry for a five-year period. 
most appropriate management and investment strategies for maximizing the net asset value of the mutual funds or their own wealth.

Such an analysis of the socio-cultural determinants of mutual fund development is the central contribution of our article. We find that a high level of happiness and the increased perception of freedom of choice are related to a more developed mutual fund industry. We also prove that individuals' preference for public ownership is associated with a less developed mutual fund industry. However, this effect disappears when the variable is interacted with the level of economic development.

The remainder of the paper is organized as follows. In Section 2 we take the opportunity to review some of the previous research on the different socio-cultural determinants of financial decision-making and to state our hypotheses. Section 3 describes the construction of the database and the methodology we implement. Section 4 presents our key results and section 5 concludes.

\section{Socio-Cultural Values and Investment Behaviour: Related Studies and Hypotheses Development}

Socio-cultural variables have been used by economists to explain the variability of financial practices across the world. Recent review articles on the emerging subfield of cultural finance (Breuer and Quinten, 2009; Reuter, 2011) document the adoption of cultural and social variables from management studies where they were promoted as explaining factors by the classical work of Geert Hofstede (1980). Among the numerous definitions of culture used in the literature, we choose the following as the most comprehensive: "[culture is] a complex entity of cognitions, shared by the members of a social group. The focal point of the cognitions is (core) values, which are assumed to steer individual behaviour" (Breuer and Quinten, 2009, p. 6).

We start from the growing body of literature analysing the impact of socio-cultural variables such as religion, trust, or happiness on economic development. Based on the channels through which cultural values influence financial decision-making outlined in the existing literature, we establish a link with the development of the mutual fund industry. Thus, classic theories of development paid little attention to religion and religiosity despite the fact that the religious ideas played a significant role in the development of capitalism in Europe (starting from Weber, 2005 [1930]) by shaping, for example, the moral values driving the lending, saving, and investing of money. Religion can be analysed from the perspective of the degree of religiosity of various populations but also based on the values and beliefs specific to each religion. For instance, while Weber's classical investigation of the origins of Western European capitalism argues that the development of capitalism is closely linked to Protestant thriftiness (Weber, 2005 [1930]), recent studies show that similar principles are also present in other religions (especially in Catholicism) making such cultural and religious configurations of values compatible with economic development. Therefore, it can be expected that the degree of religiosity reinforces the values associated with a particular religion but also promotes other societal features such as the level of trust with the effect of boosting the development of financial markets. As others have already shown, religion and the intensity of religious practice affect social interactions and attitudes (Brooks, 2003). Several other experimental studies on this issue, however, show mixed results (Brañas-Garza et al., 2013 for a survey on this subject) and call for further investigations of the subject. 
Several studies find direct and indirect links between religious values and beliefs and the investment decision as well as their impact on the financial markets. Thus, religiosity is positively related with risk aversion (Miller and Hoffmann, 1995) and it increases the propensity to save (Guiso et al., 2003). Religion is also analysed in connection with happiness and trust (in others as well as in institutions) (Guiso et al., 2003). Mookerjee and Beron (2005) show that religion is related to the level of happiness registered in society. Several studies, such as Renneboog and Spaenjers (2012), find that religiosity is positively correlated with trust while religious persons reveal a preference for longer planning horizons. Investments in mutual funds are considered to be long-term oriented and less risky than other alternatives on the stock market. Therefore, we formulate the following hypothesis:

H1: The higher the degree of religiosity within a given country, the higher the size of the mutual fund industry.

Over the last two decades various studies have analysed empirically societal trust and its impact on economic outcomes. Trust, in conjunction with efficient institutions as well as social, ethical, and economic homogeneity improves the performance of an economy (Knack and Keefer, 1997; Beugelsdijk et al., 2004). Extrapolating these results, we surmise that the trust that individual and institutional investors have in asset managers and in their own financial decisions, given an uncertain financial market environment, translates into a more consistent development of mutual funds. Similarly, Guiso et al. (2008) associate trust with stock market participation. Therefore, we hypothesize that:

$\mathrm{H} 2$ : The higher the level of trust within a society, the higher the size of the mutual fund industry.

The existing literature related to happiness reveals aspects concerning both its determinants and its consequences for economic development. The relation between happiness and income is nuanced, being characterized by both positive and insignificant correlations (Frey and Stutzer, 2002; Sarracino, 2013). Despite the fact that the GDP (alongside economic growth) is generally used to show the aggregated prosperity of a nation, there are many other dimensions to reflect wellbeing, as critics argue (Stiglitz et al., 2009). For instance, subjective wellbeing (measured through questions addressed directly to people to assess the quality of their lives) is already used in the literature (Sarracino, 2013). Guven (2012) shows that happiness can generate specific patterns in consumption and saving behaviours. Thus, happier people tend to save more and to take decisions that are future oriented. This idea is in line with previous findings which indicate that the key reason for households' investment in mutual funds is saving for retirement. Based on these considerations, our third hypothesis is:

H3: The higher the level of happiness, the higher the size of the mutual fund industry.

If we assume that market oriented policies can boost the growth (Easton and Walker, 1997) and therefore the development of financial institutions and organizations, we can expect that a favourable attitude towards private ownership will positively impact the development of mutual funds. If individuals associate private ownership with mutual funds, it can reversely be expected that countries showing a favourable attitude towards public ownership would prefer other types of saving and investing than mutual funds (such as, government securities, deposits to state-owned banks, etc.). The fourth hypothesis is: 
H4: The higher the percentage of the population believing that private ownership of business should be increased, the higher the size of the mutual fund industry.

Investment behaviour could also be influenced by peoples' perception of the economic, social and political environment. Drawing on Compton and Hoffman (2012), we distinguish between countries that value individual achievements and freedom of expression and countries with collectivist cultures where people are more socially oriented and focus on group welfare rather than individual wealth. Using this dichotomy, we formulate our last hypothesis:

H5: The higher the freedom of choice in a country, the higher the size of the mutual fund industry.

We expect the effect of socio-cultural values to be significant due to the fact that a mutual fund is a type of institutional investor whose behaviour is shaped by both managers and investors, each of these categories of agents acting based on their own socio-cultural norms (Kaminsky et al., 2004).

\section{Data and Methodology}

This paper studies the impact of socio-cultural values on the size of the mutual fund industry in 38 countries, including 22 developed and 16 emerging countries $^{3}$. The dependent variable is defined both as the ratio of net total assets to GDP (NAV/GDP) and as the net total assets scaled by the country's population (NAV/POP). In order to ensure data consistency, we use only the data series of total net assets (in US\$ millions) made available by the Investment Company Institute (http://www.ici.org/research/stats).

Socio-cultural variables were obtained from the World Values Survey (WVS) database (http://www.worldvaluessurvey.org/WVSOnline.jsp), using the answers of the distinct waves of surveys conducted during the analysed period ${ }^{4}$. Drawing on the associations between socio-cultural values and financial behaviours identified in the literature, we decided to focus our analysis on variables such as: the degree of religiosity (religious person), the level of trust in people (trust), the level of happiness (happiness), the preference of individuals for different types of ownership (public versus private ownership) and the perception of individuals regarding the ability to control their lives (free choice). A detailed definition of each variable is presented in Appendix A.

As control variables, we took into account several determinants used in previous empirical research to measure the development of the securities markets, of the banking system, of the overall financial system and, more specifically, of the mutual fund industry. Specifically, we used the ratio of stock market total value traded to GDP (SM traded value) as in Klapper et al.(2004) and Ferreira et al.(2013), the ratio of liquid liabilities in the economy

3 Our sample contains the following high-income countries: Australia, Austria, Belgium, Canada, Denmark, Finland, France, Germany, Greece, Italy, Japan, Republic of Korea, the Netherlands, New Zealand, Norway, Portugal, Slovenia, Spain, Sweden, Switzerland, the United Kingdom, and the United States. The upper-middle income and lower-middle income countries are: Argentina, Brazil, the Czech Republic, Chile, China, Hungary, India, Mexico, Pakistan, Philippines, Poland, Romania, Russia, Slovakia, South Africa, and Turkey. This divide reproduces the World Bank classification for the analysed period.

4 WVS is an exhaustive worldwide database investigating human believes and values based on surveys carried out periodically (http://www.worldvaluessurvey.org/WVSContents.jsp). 
to GDP (liquid liabilities ratio), the ratio of remittance inflows to GDP (remittance), the ratio of international debt issues to GDP (international debt), and an indicator measuring the fraction of assets held by the top three banks in the system (bank concentration) as in Khorana et al. (2005). All these variables are from the datasets of Beck et al. (2000), last updated in November $2011^{5}$.

We used data from the World Development Indicators (WDI) to include a dummy variable for developed countries (developed [D]), to calculate real interest rates (real interest rate) as in Klapper et al. (2004), and the ratio of total imports and exports to GDP6 (openness) as in Klapper et al. (2004). Developed [D] is a dummy variable equal to 1 if the country is developed according to the World Bank classification and 0 otherwise.

We use average years of secondary schooling (school years [sec]) as in Khorana et al. $(2005)^{7}$, the age of the mutual fund industry in each country ${ }^{8}$ (industry age) as in Khorana et al. (2005), and a dummy variable for Common law countries as in La Porta et al. (1998). Common law is a dummy variable equal to 1 for a country with British legal origin and 0 otherwise. Economic theory seems to reinforce practical observations that common law is conductive of capital markets and mutual funds development, both being linked to the degree of investor rights protection (La Porta et al., 1998; Djankov et al., 2008). Finally, we use dummies for the data in the fourth and fifth waves of the World Values Survey.

As socio-cultural variables are not covered on an annual basis but are recorded at different intervals of time, we divided our dataset in three sub-periods associated with each wave of the WVS that occurred during the entire period considered in our analysis: 1996-1998 associated with the third WVS wave, 1999-2004 associated with the fourth WVS wave, and 2005-2009 associated with the fifth WVS wave. This procedure allows us to increase the number of observations relative to a pure cross-section model. We took into account the mean values for both dependent and control variables for each of the subperiods corresponding to the waves of the WVS. ${ }^{9}$ For socio-cultural variables, we used the value available from the selected waves of the survey, similar to the methodology applied by Knack and Keefer (1997).

We test our hypotheses using the regression model described below:

$$
Y_{i, t}=\alpha_{i}+\beta X_{i, t}+\gamma Z_{i, t}+\theta T_{i, t}+u_{i, t}
$$

Where, $Y_{i, t}$ represents the size of the mutual fund industry measured by the mean NAV/GDP and the mean NAV/POP for country $i$ in the sub-period $t, X_{i, t}$ is a vector of socio-cultural

5 The Financial Development and Structure dataset is a cross-country, time series database containing data from 1960 through 2009 (www.econ.worldbank.org).

6 Some studies emphasise the separation of financial and trade openness (e.g. Prasad et al., 2007). Openness to international trade can measure the degree of integration with foreign markets and is expected to have a positive impact on the development of mutual fund industries.

7 This variable is part of a worldwide dataset of educational attainment provided by Barro and Lee (2013) that contains data from 1950 to 2010 covering 145 countries (http://www.barrolee.com/).

8 As a measure of industry development, we used the industry age based on the assumption that the creation of a mutual fund or the legal provisions for this industry alone are not sufficient to determine positive effects on the economy (Khorana et al., 2005; Ferreira et al., 2013).

9 The only exception is school years for which the values correspond to 1995, 2000 and 2005. 
variables, $Z_{i, t}$ is the vector of control variables, and the term $T_{i, t}$ represents sub-period dummies. Due to the strong interdependence between socio-cultural variables (Guiso et al., 2006; Sarracino, 2013), we test them in separate regressions. Moreover, as our database is formed by countries with different degrees of economic development that can induce a different perception of socio-cultural aspects, as a robustness check, we also report regressions including interaction terms between socio-cultural variables and a dummy for economic development.

Due to the reduced number of observations of the dataset, the implementation of the OLS regression could lead to misleading results. We conduct additional statistical tests which allow us to validate the results. Firstly, we checked for the existence of outliers. We excluded Luxembourg, Ireland, and Hong Kong given their abnormal ratios of net asset values to GDP and very high net asset values per capita. Klapper et al. (2004) and Khorana et al. (2005) also excluded two outliers, Luxembourg and Ireland, from their analysis. Supplementary tests based on studentized residuals indicated Australia (for the third sub-period) as an extreme outlier; therefore this observation was not included in our analysis.

Secondly, in order to validate the statistical significance of t-statistics, when appropriate, we applied logarithmic transformations to the initial data series ${ }^{10}$. In addition, for each regression, we applied the Shapiro-Wilk W test to check for the normality of residuals. OLS regressions with a reduced number of observations could also be affected by multicolinearity. Therefore, we studied the correlations among the independent variables as well as the variance inflation factor (VIF) for each variable in all specifications. The pairwise correlation matrix ${ }^{11}$ shows that none of the correlation coefficient is higher than 0.7. Moreover, the variance inflation factor does not exceeds 5 (and is lower than 2.5 for the social-cultural variables). Therefore, there is no clear indication of a multicolinearity problem. ${ }^{12}$

\section{Determinants of Development of the Mutual Fund Industry: Impact of Socio-Cultural Variables}

Tables 1-5 present the results of the impact of socio-cultural variables on the size of mutual fund industry, controlling for determinants of socio-economic and financial development. We found no robust influence of the level of religiosity on the size of mutual fund industry (Table 1). Therefore, we reject our first hypothesis. However, considering that religious individuals present specific values and beliefs that could be reflected in other aspects, it is possible that the impact of religiosity is reflected indirectly through other variables like happiness and trust (Mookerjee and Beron, 2005; Renneboog and Spaenjers, 2012).

Among the control variables, stock market traded value, remittances, and industry age seems to be robust determinants of the development of mutual funds (these results are also supported by our subsequent analyses). We found a strong and positive relation between the capital market development/liquidity (measured by the proxy of stock market

10 We apply the logarithmic transformation to the following variables: NAV/GDP, NAV/POP, stock market traded value, liquid liabilities ratio, remittances, international debt, openness and industry age.

11 The pairwise correlation matrix is available from the authors upon request.

12 The interaction variables were not considered in this analysis. 
total value traded) and the size of the mutual fund industry. Moreover, through the positive and significant coefficient of the industry age variable, the maturity of the mutual fund industry explains some of the differences in its size across countries. These results are in line with previous findings of Klapper et al. (2004) and Khorana et al. (2005). The significantly negative impact of the ratio of remittance inflows to GDP on the size of the mutual fund industry can be explained by the destination of this money that seems to be used for consumption rather than for savings or capital market investments. In a recent study, Stojanov and Strielkowski (2013) show that remittances by migrants have a positive impact on the economies of lower-middle income and low-income countries. Moreover, they underlined the fact that "remittances provide more opportunities for being used by the poor recipients on the basis of their free will (e.g. consumption, investments, education, health care, houses building, reconstruction, etc.)" (Stojanov and Strielkowski, 2013, p. 10).

In all the equations reported in Tables $1-5$, the statistically significant results for the ratio of liquid liabilities to GDP highlight a positive impact on the size of the mutual fund industry. However, this relationship disappears when the degree of country development is taken into consideration. This result could be explained through the preference for consumption, especially in middle- and lower-income countries, or based on cultural values that discourage risky investments. It is rather to be expected as economic development is associated with a prevalence of more elaborate monetary and financial instruments within the money mass.

Considering the overall results, bank concentration reveals no robust influence on the size of mutual funds. Indeed, these findings could be interpreted as in Yartey (2008) regarding the non-monotonic link between banking sector development and stock market development. Moreover, Khorana et al. (2005) showed that bank concentration is negatively related with the bond fund sector and has no impact on the equity fund sector so our results are somehow in line with previous findings.

We find no robust influence of openness to international trade, international debt, education, real interest rate and common law ${ }^{13}$ on our dependent variables. The coefficients for international debt and openness are weakly significant when the variable for economic development is not included in the estimations. This might indicate at the most an indirect effect through economic development on the development of mutual funds but no significant direct influence on the growth of the sector. The interest rates and the spread between bank deposits and money market funds is expected to exert a significant influence on the demand of money market and short-term bond mutual funds. Klapper et al. (2004) claim that equity mutual funds are likely to be affected by this spread in cases where real returns are much higher than real interest rates and if their volatility is not high. They also find this variable to be statistically insignificant for developed countries. Also, we are able to confirm the results of Korana et al. (2005) who found that education is not relevant for the development of bond mutual funds.

13 This variable remains insignificant even when interacted with differences in countries' development. 
Table 1 | Estimated Impact of the Religiosity on the Size of the Mutual Fund Industry

This table reports the results of OLS regressions with robust standard errors for the impact of the level of religiosity on mutual fund industry size across countries for the period 1996-2009, controlling for economic and financial development.

\begin{tabular}{|c|c|c|c|c|}
\hline \multirow{2}{*}{ Dependent variable } & \multicolumn{2}{|c|}{ NAV/GDP } & \multicolumn{2}{|c|}{ NAV/POP } \\
\hline & (1) & (2) & (3) & (4) \\
\hline Religious person & $\begin{array}{l}1.202 \\
(1.49)\end{array}$ & $\begin{array}{l}-0.963 \\
(-0.47)\end{array}$ & $\begin{array}{l}1.850^{*} \\
(1.84)\end{array}$ & $\begin{array}{l}-0.438 \\
(-0.15)\end{array}$ \\
\hline Developed (D) & & $\begin{array}{c}-0.0330 \\
(-0.02)\end{array}$ & & $\begin{array}{l}1.125 \\
(0.50)\end{array}$ \\
\hline Religious person*Developed (D) & & $\begin{array}{l}2.493 \\
(1.24)\end{array}$ & & $\begin{array}{l}2.490 \\
(0.88)\end{array}$ \\
\hline SM traded value & $\begin{array}{l}0.569^{* * *} \\
(3.73)\end{array}$ & $\begin{array}{l}0.449^{* * *} \\
(2.98)\end{array}$ & $\begin{array}{l}0.528^{* * *} \\
(2.90)\end{array}$ & $\begin{array}{l}0.344^{* *} \\
(2.10)\end{array}$ \\
\hline Liquid liabilities ratio & $\begin{array}{l}0.584^{* *} \\
(2.02)\end{array}$ & $\begin{array}{c}-0.00259 \\
(-0.01)\end{array}$ & $\begin{array}{l}1.274^{* * *} \\
(3.45)\end{array}$ & $\begin{array}{l}0.317 \\
(0.70)\end{array}$ \\
\hline Remittance & $\begin{array}{l}-0.239^{* *} \\
(-2.51)\end{array}$ & $\begin{array}{l}-0.296^{* * *} \\
(-2.76)\end{array}$ & $\begin{array}{l}-0.368^{* *} \\
(-2.53)\end{array}$ & $\begin{array}{l}-0.474^{* * * *} \\
(-2.98)\end{array}$ \\
\hline Real interest rate & $\begin{array}{l}0.913 \\
(0.56)\end{array}$ & $\begin{array}{l}1.176 \\
(0.76)\end{array}$ & $\begin{array}{l}1.015 \\
(0.45)\end{array}$ & $\begin{array}{l}1.490 \\
(0.70)\end{array}$ \\
\hline School years (sec) & $\begin{array}{c}-0.0696 \\
(-0.35)\end{array}$ & $\begin{array}{l}-0.545^{* *} \\
(-2.07)\end{array}$ & $\begin{array}{l}0.518^{* *} \\
(2.10)\end{array}$ & $\begin{array}{l}-0.264 \\
(-0.80)\end{array}$ \\
\hline International debt & $\begin{array}{c}0.0892 \\
(0.66)\end{array}$ & $\begin{array}{c}-0.0935 \\
(-0.68)\end{array}$ & $\begin{array}{l}0.433^{* *} \\
(2.52)\end{array}$ & $\begin{array}{l}0.136 \\
(0.77)\end{array}$ \\
\hline Openness & $\begin{array}{c}0.0209 \\
(0.05)\end{array}$ & $\begin{array}{l}0.320 \\
(0.81)\end{array}$ & $\begin{array}{l}-0.383 \\
(-0.76)\end{array}$ & $\begin{array}{l}0.244 \\
(0.51)\end{array}$ \\
\hline Bank concentration & $\begin{array}{l}1.674^{* *} \\
(2.22)\end{array}$ & $\begin{array}{l}0.879 \\
(1.30)\end{array}$ & $\begin{array}{l}3.223^{* * * *} \\
(3.33)\end{array}$ & $\begin{array}{l}1.735^{* *} \\
(2.10)\end{array}$ \\
\hline Industry age & $\begin{array}{l}0.755^{* * *} \\
(2.78)\end{array}$ & $\begin{array}{l}0.781^{* * *} \\
(3.14)\end{array}$ & $\begin{array}{l}0.739^{*} \\
(1.95)\end{array}$ & $\begin{array}{l}0.741^{* *} \\
(2.20)\end{array}$ \\
\hline Common law & $\begin{array}{c}-0.0254 \\
(-0.09)\end{array}$ & $\begin{array}{c}0.0877 \\
(0.31)\end{array}$ & $\begin{array}{l}-0.462 \\
(-1.26)\end{array}$ & $\begin{array}{l}-0.223 \\
(-0.68)\end{array}$ \\
\hline Fourth WVS wave (D) & $\begin{array}{l}0.312 \\
(1.00)\end{array}$ & $\begin{array}{l}0.530^{*} \\
(1.71)\end{array}$ & $\begin{array}{l}-0.0141 \\
(-0.04)\end{array}$ & $\begin{array}{l}0.332 \\
(0.92)\end{array}$ \\
\hline Fifth WVS wave (D) & $\begin{array}{l}-0.263 \\
(-0.79)\end{array}$ & $\begin{array}{l}0.395 \\
(1.11)\end{array}$ & $\begin{array}{l}-0.363 \\
(-0.91)\end{array}$ & $\begin{array}{l}0.646 \\
(1.43)\end{array}$ \\
\hline Constant & $\begin{array}{l}-7.200^{* * *} \\
(-3.33)\end{array}$ & $\begin{array}{l}-7.116^{* * *} \\
(-2.73)\end{array}$ & $\begin{array}{l}-6.005^{* *} \\
(-2.18)\end{array}$ & $\begin{array}{l}-7.170^{* *} \\
(-2.14)\end{array}$ \\
\hline$N$ & 63 & 63 & 63 & 63 \\
\hline adj. $R^{2}$ & 0.699 & 0.733 & 0.752 & 0.795 \\
\hline Shapiro-Wilk W test (p-values) & 0.219 & 0.299 & 0.087 & 0.055 \\
\hline
\end{tabular}

Notes: Robust $t$ statistics in parentheses, ${ }^{*} p<0.10,{ }^{* *} p<0.05,{ }^{* * *} p<0.01$

The Shapiro-Wilk $W$ test is based on a null hypothesis that the population is normally distributed. 
Table 2 | Estimated Impact of Trust on the Size of the Mutual Fund Industry

This table reports the results of OLS regressions with robust standard errors for the impact of trust on mutual fund industry size across countries for the period 1996-2009, controlling for economic and financial development.

\begin{tabular}{|c|c|c|c|c|}
\hline \multirow{2}{*}{ Dependent variable } & \multicolumn{2}{|c|}{ NAV/GDP } & \multicolumn{2}{|c|}{ NAV/POP } \\
\hline & (1) & (2) & (3) & (4) \\
\hline Trust & $\begin{array}{l}-0.309 \\
(-0.25)\end{array}$ & $\begin{array}{l}0.464 \\
(0.10)\end{array}$ & $\begin{array}{l}0.403 \\
(0.22)\end{array}$ & $\begin{array}{l}-1.237 \\
(-0.18)\end{array}$ \\
\hline Developed (D) & & $\begin{array}{l}2.541^{* *} \\
(2.10)\end{array}$ & & $\begin{array}{l}3.009 \\
(1.52)\end{array}$ \\
\hline Trust*Developed (D) & & $\begin{array}{l}-1.905 \\
(-0.37) \\
\end{array}$ & & $\begin{array}{l}0.551 \\
(0.07) \\
\end{array}$ \\
\hline SM traded value & $\begin{array}{l}0.569^{* * *} \\
(3.41)\end{array}$ & $\begin{array}{l}0.459^{* *} \\
(2.64) \\
\end{array}$ & $\begin{array}{l}0.482^{* *} \\
(2.64) \\
\end{array}$ & $\begin{array}{l}0.354^{*} \\
(1.89) \\
\end{array}$ \\
\hline Liquid liabilities ratio & $\begin{array}{l}0.347 \\
(1.29) \\
\end{array}$ & $\begin{array}{l}-0.290 \\
(-0.86)\end{array}$ & $\begin{array}{l}0.962^{* * *} \\
(2.73)\end{array}$ & $\begin{array}{c}0.0493 \\
(0.11) \\
\end{array}$ \\
\hline Remittance & $\begin{array}{l}-0.201^{*} \\
(-2.00) \\
\end{array}$ & $\begin{array}{l}-0.311^{* * *} \\
(-2.84)\end{array}$ & $\begin{array}{c}-0.323^{* *} \\
(-2.16)\end{array}$ & $\begin{array}{c}-0.448^{* *} \\
(-2.40)\end{array}$ \\
\hline Real interest rate & $\begin{array}{l}1.135 \\
(0.67)\end{array}$ & $\begin{array}{l}1.573 \\
(0.69)\end{array}$ & $\begin{array}{l}1.478 \\
(0.65)\end{array}$ & $\begin{array}{l}1.516 \\
(0.51)\end{array}$ \\
\hline School years (sec) & $\begin{array}{c}-0.0861 \\
(-0.34) \\
\end{array}$ & $\begin{array}{c}-0.562^{*} \\
(-1.88) \\
\end{array}$ & $\begin{array}{l}0.400 \\
(1.22) \\
\end{array}$ & $\begin{array}{l}-0.319 \\
(-0.85) \\
\end{array}$ \\
\hline International debt & $\begin{array}{c}0.0760 \\
(0.52) \\
\end{array}$ & $\begin{array}{l}-0.126 \\
(-0.70)\end{array}$ & $\begin{array}{l}0.470^{* *} \\
(2.60)\end{array}$ & $\begin{array}{l}0.137 \\
(0.67)\end{array}$ \\
\hline Openness & $\begin{array}{l}0.248 \\
(0.53) \\
\end{array}$ & $\begin{array}{l}0.657 \\
(1.60) \\
\end{array}$ & $\begin{array}{l}-0.143 \\
(-0.26) \\
\end{array}$ & $\begin{array}{l}0.482 \\
(1.05) \\
\end{array}$ \\
\hline Bank concentration & $\begin{array}{l}0.977 \\
(1.01)\end{array}$ & $\begin{array}{l}0.460 \\
(0.47)\end{array}$ & $\begin{array}{l}2.332^{* *} \\
(2.06)\end{array}$ & $\begin{array}{l}1.207 \\
(1.08)\end{array}$ \\
\hline Industry age & $\begin{array}{l}0.891^{* * *} \\
(2.88)\end{array}$ & $\begin{array}{l}0.825^{* * *} \\
(3.31)\end{array}$ & $\begin{array}{l}0.875^{* *} \\
(2.17) \\
\end{array}$ & $\begin{array}{l}0.731^{* *} \\
(2.44) \\
\end{array}$ \\
\hline Common law & $\begin{array}{c}-0.0867 \\
(-0.26) \\
\end{array}$ & $\begin{array}{c}0.0667 \\
(0.20) \\
\end{array}$ & $\begin{array}{l}-0.376 \\
(-0.95) \\
\end{array}$ & $\begin{array}{c}-0.0986 \\
(-0.27) \\
\end{array}$ \\
\hline Fourth WVS wave (D) & $\begin{array}{l}0.181 \\
(0.52) \\
\end{array}$ & $\begin{array}{l}0.483 \\
(1.52) \\
\end{array}$ & $\begin{array}{c}-0.0689 \\
(-0.17) \\
\end{array}$ & $\begin{array}{l}0.372 \\
(1.00) \\
\end{array}$ \\
\hline Fifth WVS wave (D) & $\begin{array}{l}-0.410 \\
(-0.97) \\
\end{array}$ & $\begin{array}{l}0.308 \\
(0.79) \\
\end{array}$ & $\begin{array}{l}-0.385 \\
(-0.79) \\
\end{array}$ & $\begin{array}{l}0.613 \\
(1.12) \\
\end{array}$ \\
\hline Constant & $\begin{array}{l}-7.005^{* * *} \\
(-3.09)\end{array}$ & $\begin{array}{l}-9.537^{* * *} \\
(-3.84)\end{array}$ & $\begin{array}{l}-5.236^{*} \\
(-1.86)\end{array}$ & $\begin{array}{c}-7.853^{* *} \\
(-2.36) \\
\end{array}$ \\
\hline$N$ & 64 & 64 & 64 & 64 \\
\hline adj. $R^{2}$ & 0.659 & 0.709 & 0.731 & 0.783 \\
\hline Shapiro-Wilk W test (p-values) & 0.794 & 0.397 & 0.079 & 0.021 \\
\hline
\end{tabular}

Notes: Robust $t$ statistics in parentheses, ${ }^{*} p<0.10,{ }^{* *} p<0.05,{ }^{* * * *} p<0.01$

The Shapiro-Wilk $W$ test is based on a null hypothesis that the population is normally distributed. 
Table 2 shows the relation between the size of mutual fund sector and trust. In all specifications, the coefficients for trust were not statistically significant. We are able to reject our second hypothesis. These results can be explained by the dual implication of trust. On one hand, previous studies have linked trust with an increased confidence in financial institutions and we expected trustworthy individuals to be less risk averse and more willing to invest in collective projects like mutual funds. However, there is evidence that even if trust increases stock market participation, trusting individuals invest a higher amount of their wealth in stocks (Guiso et al., 2008). Therefore, the absence of the correlation between trust and the development of mutual fund industry can reveal a higher propensity of investing in riskier alternatives available on the financial markets.

Table 3 presents the results of the impact of happiness on mutual fund development. In accord with our third hypothesis, the level of happiness is directly related to the size of the mutual fund industry and is significant throughout all tested models. Happier people have a greater propensity to save and invest, and prefer long-term investments. Moreover, when we test whether this relationship varies with differences in country development, the results show that the impact of happiness is even stronger in less developed countries. The World Happiness Report (Helliwell et al., 2013) ${ }^{14}$ identifies the factors that affect happiness as income, education, health, personal and economic security, personal freedom, the lack of corruption, and the quality of the environment. Life satisfaction is not necessarily the same as human development as "a grumbling rich man may well be less happy than a contented peasant, but he does have a higher standard of living than that peasant" (Sen, 1983, p. 160). The empirical analysis made in this report proves that the determinants of happiness and the goals of human development are connected even if this link is not as strong as it seems to be at first sight.

The results reported in Table 4 and Table 5 reveal the influence of the preference for public or private ownership and of the freedom of choice (two variables measuring values associated with particular political ideals and ownership arrangements) on the size of the mutual fund industry in the countries included in our sample.

Consistent with our forth hypothesis, Equations 1 and Equations 3 in Table 4 reflect a negative correlation between the preference for public ownership and the size of the mutual fund industry. The prevalence of public ownership could imply less developed capital markets, a lower degree of financial openness and, in general, a less efficient economy. In this context, it is expected that the mutual fund industry will be more developed in countries where people prefer private ownership to government ownership. However, the results should be interpreted with caution considering that the coefficient of public ownership variable becomes statistically insignificant when the interaction with the degree of development is added.

We also find the expected and statistically significant influence of the free choice variable on the size of the mutual fund industry (Equations 1-4 from Table 5). We are thus able to confirm our fifth hypothesis. If investors believe that they have freedom of choice and control over their lives, such socio-political values will positively influence the preference for financial investments in capital markets through mutual funds. Moreover, the statistical significance of this variable is enhanced by the introduction of the interaction with the variable coding for economic development. However, the impact of freedom of choice seems to be only marginally higher in the emerging countries relative to the developed ones.

14 http://unsdsn.org/wp-content/uploads/2014/02/WorldHappinessReport2013_online.pdf 
Table 3 | Estimated Impact of the Level of Happiness on the Size of the mutual Fund Industry

This table reports the results of OLS regressions with robust standard errors for the impact of the level of happiness on mutual fund industry size across countries for the period 1996-2009, controlling for economic and financial development.

\begin{tabular}{|c|c|c|c|c|}
\hline \multirow{2}{*}{ Dependent variable } & \multicolumn{2}{|c|}{ NAV/GDP } & \multicolumn{2}{|c|}{ NAV/GDP } \\
\hline & (1) & (2) & (3) & (4) \\
\hline Happiness & $\begin{array}{l}6.964^{* * *} \\
(5.34) \\
\end{array}$ & $\begin{array}{l}7.947^{* * *} \\
(5.33)\end{array}$ & $\begin{array}{l}9.423^{* * *} \\
(5.00)\end{array}$ & $\begin{array}{c}9.863^{* * *} \\
(4.41)\end{array}$ \\
\hline Developed (D) & & $\begin{array}{l}10.01^{* * *} \\
(3.93)\end{array}$ & & $\begin{array}{c}9.591^{* * *} \\
(3.27)\end{array}$ \\
\hline Happiness*Developed (D) & & $\begin{array}{c}-9.737^{* * *} \\
(-3.26)\end{array}$ & & $\begin{array}{l}-8.164^{* *} \\
(-2.25) \\
\end{array}$ \\
\hline SM traded value & $\begin{array}{l}0.520^{* * *} \\
(3.58)\end{array}$ & $\begin{array}{l}0.402^{* * *} \\
(2.89)\end{array}$ & $\begin{array}{l}0.440^{* * *} \\
(2.76)\end{array}$ & $\begin{array}{l}0.278^{*} \\
(1.90)\end{array}$ \\
\hline Liquid liabilities ratio & $\begin{array}{l}0.0675 \\
(0.29)\end{array}$ & $\begin{array}{l}-0.383 \\
(-1.34)\end{array}$ & $\begin{array}{l}0.554^{*} \\
(1.97)\end{array}$ & $\begin{array}{l}-0.153 \\
(-0.45)\end{array}$ \\
\hline Remittance & $\begin{array}{c}-0.229^{* *} \\
(-2.56)\end{array}$ & $\begin{array}{l}-0.301^{* * *} \\
(-3.29)\end{array}$ & $\begin{array}{c}-0.354^{* *} \\
(-2.50)\end{array}$ & $\begin{array}{c}-0.466^{* * *} \\
(-3.26)\end{array}$ \\
\hline Real interest rate & $\begin{array}{l}1.582 \\
(1.30) \\
\end{array}$ & $\begin{array}{l}2.288^{*} \\
(1.85) \\
\end{array}$ & $\begin{array}{l}1.776 \\
(1.07) \\
\end{array}$ & $\begin{array}{l}2.543 \\
(1.54) \\
\end{array}$ \\
\hline School years (sec) & $\begin{array}{l}-0.193 \\
(-1.11) \\
\end{array}$ & $\begin{array}{c}-0.409^{*} \\
(-1.71)\end{array}$ & $\begin{array}{l}0.341 \\
(1.50)\end{array}$ & $\begin{array}{l}-0.152 \\
(-0.50)\end{array}$ \\
\hline International debt & $\begin{array}{c}-0.0293 \\
(-0.23)\end{array}$ & $\begin{array}{l}-0.157 \\
(-1.20)\end{array}$ & $\begin{array}{l}0.277^{*} \\
(1.79)\end{array}$ & $\begin{array}{c}0.0677 \\
(0.40)\end{array}$ \\
\hline Openness & $\begin{array}{l}0.341 \\
(0.79) \\
\end{array}$ & $\begin{array}{l}0.833^{* *} \\
(2.31) \\
\end{array}$ & $\begin{array}{c}-0.0852 \\
(-0.18) \\
\end{array}$ & $\begin{array}{l}0.590 \\
(1.60) \\
\end{array}$ \\
\hline Bank concentration & $\begin{array}{l}0.438 \\
(0.51) \\
\end{array}$ & $\begin{array}{l}-0.182 \\
(-0.27) \\
\end{array}$ & $\begin{array}{l}1.929^{*} \\
(1.99)\end{array}$ & $\begin{array}{l}0.877 \\
(1.19)\end{array}$ \\
\hline Industry age & $\begin{array}{c}0.462^{* *} \\
(2.04)\end{array}$ & $\begin{array}{l}0.423^{* *} \\
(2.23)\end{array}$ & $\begin{array}{l}0.327 \\
(1.09)\end{array}$ & $\begin{array}{l}0.253 \\
(1.02)\end{array}$ \\
\hline Common law & $\begin{array}{l}0.279 \\
(1.08)\end{array}$ & $\begin{array}{c}0.715^{* * *} \\
(2.70)\end{array}$ & $\begin{array}{c}-0.0397 \\
(-0.12)\end{array}$ & $\begin{array}{l}0.458 \\
(1.41) \\
\end{array}$ \\
\hline Fourth WVS wave (D) & $\begin{array}{l}0.726^{* *} \\
(2.34)\end{array}$ & $\begin{array}{l}0.819^{* * *} \\
(3.04)\end{array}$ & $\begin{array}{l}0.568 \\
(1.54)\end{array}$ & $\begin{array}{l}0.827^{* *} \\
(2.64)\end{array}$ \\
\hline Fifth WVS wave (D) & $\begin{array}{c}0.0317 \\
(0.10)\end{array}$ & $\begin{array}{l}0.489 \\
(1.46) \\
\end{array}$ & $\begin{array}{l}0.126 \\
(0.35) \\
\end{array}$ & $\begin{array}{l}0.923^{* *} \\
(2.03) \\
\end{array}$ \\
\hline Constant & $\begin{array}{l}-12.24^{* * *} \\
(-5.44)\end{array}$ & $\begin{array}{l}-15.78^{* * *} \\
(-7.69)\end{array}$ & $\begin{array}{l}-12.34^{* * *} \\
(-4.68)\end{array}$ & $\begin{array}{l}-16.12^{* * *} \\
(-6.86)\end{array}$ \\
\hline$N$ & 63 & 63 & 63 & 63 \\
\hline adj. $R^{2}$ & 0.763 & 0.822 & 0.814 & 0.862 \\
\hline Shapiro-Wilk W test (p-values) & 0.601 & 0.928 & 0.008 & 0.056 \\
\hline
\end{tabular}

Notes: Robust $t$ statistics in parentheses, ${ }^{*} p<0.10,{ }^{* *} p<0.05,{ }^{* * *} p<0.01$

The Shapiro-Wilk $W$ test is based on a null hypothesis that the population is normally distributed. 
Table 4 | Estimated Impact of the Preference for Public or Private Ownership on the Size of the Mutual Fund Industry

This table reports the results of OLS regressions with robust standard errors for the impact of the preference for public or private ownership on mutual fund industry size across countries for the period 1996-2009, controlling for economic and financial development.

\begin{tabular}{|c|c|c|c|c|}
\hline \multirow{2}{*}{ Dependent variable } & \multicolumn{2}{|c|}{ NAV/GDP } & \multicolumn{2}{|c|}{ NAV/POP } \\
\hline & (1) & (2) & (3) & (4) \\
\hline Public versus private ownership & $\begin{array}{c}-53.37^{*} \\
(-1.69) \\
\end{array}$ & $\begin{array}{l}-24.68 \\
(-0.61) \\
\end{array}$ & $\begin{array}{c}-85.31^{* *} \\
(-2.05)\end{array}$ & $\begin{array}{l}-51.06 \\
(-0.93) \\
\end{array}$ \\
\hline Developed (D) & & $\begin{array}{l}4.490 \\
(1.47)\end{array}$ & & $\begin{array}{l}5.347 \\
(1.50)\end{array}$ \\
\hline $\begin{array}{l}\text { Public versus private* } \\
\text { Developed (D) }\end{array}$ & & $\begin{array}{l}-54.64 \\
(-0.93)\end{array}$ & & $\begin{array}{l}-56.74 \\
(-0.83)\end{array}$ \\
\hline SM traded value & $\begin{array}{l}0.662^{* * *} \\
(3.53)\end{array}$ & $\begin{array}{l}0.609^{* * *} \\
(2.91)\end{array}$ & $\begin{array}{l}0.628^{* * *} \\
(2.96)\end{array}$ & $\begin{array}{l}0.528^{* *} \\
(2.31)\end{array}$ \\
\hline Liquid liabilities ratio & $\begin{array}{l}0.130 \\
(0.39)\end{array}$ & $\begin{array}{l}-0.404 \\
(-0.97)\end{array}$ & $\begin{array}{l}0.634 \\
(1.50)\end{array}$ & $\begin{array}{l}-0.110 \\
(-0.21)\end{array}$ \\
\hline Remittance & $\begin{array}{l}-0.192^{*} \\
(-1.73)\end{array}$ & $\begin{array}{l}-0.295^{* *} \\
(-2.64)\end{array}$ & $\begin{array}{l}-0.306^{* *} \\
(-2.07)\end{array}$ & $\begin{array}{l}-0.446^{* * *} \\
(-2.91)\end{array}$ \\
\hline Real interest rate & $\begin{array}{l}0.917 \\
(0.65)\end{array}$ & $\begin{array}{l}1.006 \\
(0.71)\end{array}$ & $\begin{array}{l}0.741 \\
(0.42)\end{array}$ & $\begin{array}{l}0.960 \\
(0.55)\end{array}$ \\
\hline School years (sec) & $\begin{array}{l}-0.373 \\
(-1.57)\end{array}$ & $\begin{array}{l}-0.898^{* * *} \\
(-3.02)\end{array}$ & $\begin{array}{l}0.0237 \\
(0.08)\end{array}$ & $\begin{array}{l}-0.676^{*} \\
(-1.91)\end{array}$ \\
\hline International debt & $\begin{array}{l}0.145 \\
(0.96)\end{array}$ & $\begin{array}{l}-0.105 \\
(-0.58)\end{array}$ & $\begin{array}{l}0.551^{* * *} \\
(3.02)\end{array}$ & $\begin{array}{l}0.210 \\
(1.06)\end{array}$ \\
\hline Openness & $\begin{array}{l}0.446 \\
(0.84)\end{array}$ & $\begin{array}{l}0.818 \\
(1.54)\end{array}$ & $\begin{array}{c}-0.0539 \\
(-0.09)\end{array}$ & $\begin{array}{l}0.459 \\
(0.84)\end{array}$ \\
\hline Bank concentration & $\begin{array}{l}-0.207 \\
(-0.21)\end{array}$ & $\begin{array}{l}-0.488 \\
(-0.53)\end{array}$ & $\begin{array}{l}1.153 \\
(1.00)\end{array}$ & $\begin{array}{l}0.733 \\
(0.78)\end{array}$ \\
\hline Industry age & $\begin{array}{l}0.685^{* *} \\
(2.65)\end{array}$ & $\begin{array}{l}0.657^{* * *} \\
(3.10)\end{array}$ & $\begin{array}{l}0.560^{*} \\
(1.70)\end{array}$ & $\begin{array}{l}0.531^{* *} \\
(2.06)\end{array}$ \\
\hline Common law & $\begin{array}{l}-0.214 \\
(-0.59)\end{array}$ & $\begin{array}{l}-0.209 \\
(-0.49)\end{array}$ & $\begin{array}{l}-0.591 \\
(-1.39)\end{array}$ & $\begin{array}{l}-0.526 \\
(-1.22)\end{array}$ \\
\hline Fourth WVS wave (D) & $\begin{array}{l}0.201 \\
(0.50) \\
\end{array}$ & $\begin{array}{l}0.572 \\
(1.49) \\
\end{array}$ & $\begin{array}{c}-0.0869 \\
(-0.18)\end{array}$ & $\begin{array}{l}0.422 \\
(0.91) \\
\end{array}$ \\
\hline Fifth WVS wave (D) & $\begin{array}{l}0.283 \\
(0.58)\end{array}$ & $\begin{array}{l}0.796^{*} \\
(1.71)\end{array}$ & $\begin{array}{l}0.548 \\
(0.94)\end{array}$ & $\begin{array}{l}1.260^{* *} \\
(2.16)\end{array}$ \\
\hline Constant & $\begin{array}{l}-2.801 \\
(-0.98)\end{array}$ & $\begin{array}{c}-6.495^{* *} \\
(-2.23)\end{array}$ & $\begin{array}{l}1.928 \\
(0.56)\end{array}$ & $\begin{array}{l}-3.007 \\
(-0.96)\end{array}$ \\
\hline$N$ & 54 & 54 & 54 & 54 \\
\hline $\operatorname{adj.} R^{2}$ & 0.704 & 0.725 & 0.781 & 0.803 \\
\hline Shapiro-Wilk W test (p-values) & 0.784 & 0.842 & 0.692 & 0.909 \\
\hline
\end{tabular}

Notes: Robust $t$ statistics in parentheses, ${ }^{*} p<0.10,{ }^{* *} p<0.05,{ }^{* * *} p<0.01$

The Shapiro-Wilk $W$ test is based on a null hypothesis that the population is normally distributed. 
Table 5 | Estimated Impact of the Freedom of Choice on the Size of the Mutual Fund Industry

This table reports the results of OLS regressions with robust standard errors for the impact of the freedom of choice on mutual fund industry size across countries for the period 1996-2009, controlling for economic and financial development.

\begin{tabular}{|c|c|c|c|c|}
\hline \multirow{2}{*}{ Dependent variable } & \multicolumn{2}{|c|}{ NAV/GDP } & \multicolumn{2}{|c|}{ NAV/POP } \\
\hline & (1) & (2) & (3) & (4) \\
\hline Free choice & $\begin{array}{l}0.618^{* *} \\
(2.04)\end{array}$ & $\begin{array}{l}0.880^{* * *} \\
(2.81)\end{array}$ & $\begin{array}{l}1.110^{* * *} \\
(2.86)\end{array}$ & $\begin{array}{l}1.515^{* * *} \\
(3.92)\end{array}$ \\
\hline Developed (D) & & $\begin{array}{l}6.345^{*} \\
(1.85)\end{array}$ & & $\begin{array}{l}10.11^{* *} \\
(2.47)\end{array}$ \\
\hline Free choice* Developed (D) & & $\begin{array}{l}-0.672 \\
(-1.44)\end{array}$ & & $\begin{array}{l}-1.042^{*} \\
(-1.91)\end{array}$ \\
\hline SM traded value & $\begin{array}{l}0.643^{* * *} \\
(3.31)\end{array}$ & $\begin{array}{l}0.568^{* * *} \\
(2.85)\end{array}$ & $\begin{array}{l}0.683^{* * *} \\
(3.03)\end{array}$ & $\begin{array}{l}0.553^{* *} \\
(2.59)\end{array}$ \\
\hline Liquid liabilities ratio & $\begin{array}{l}0.697^{* *} \\
(2.47)\end{array}$ & $\begin{array}{l}0.109 \\
(0.32) \\
\end{array}$ & $\begin{array}{l}1.510^{* * *} \\
(4.50) \\
\end{array}$ & $\begin{array}{l}0.513 \\
(1.30)\end{array}$ \\
\hline Remittance & $\begin{array}{l}-0.201^{* *} \\
(-2.22)\end{array}$ & $\begin{array}{c}-0.272^{* * *} \\
(-2.72)\end{array}$ & $\begin{array}{l}-0.310^{* *} \\
(-2.37)\end{array}$ & $\begin{array}{c}-0.432^{* * *} \\
(-3.17)\end{array}$ \\
\hline Real interest rate & $\begin{array}{l}0.958 \\
(0.75)\end{array}$ & $\begin{array}{l}1.826 \\
(1.44)\end{array}$ & $\begin{array}{c}1.131 \\
(0.72)\end{array}$ & $\begin{array}{l}2.532^{*} \\
(1.70)\end{array}$ \\
\hline School years (sec) & $\begin{array}{l}-0.243 \\
(-1.20) \\
\end{array}$ & $\begin{array}{l}-0.585^{* *} \\
(-2.37)\end{array}$ & $\begin{array}{l}0.227 \\
(0.97) \\
\end{array}$ & $\begin{array}{l}-0.372 \\
(-1.29) \\
\end{array}$ \\
\hline International debt & $\begin{array}{c}0.0776 \\
(0.58) \\
\end{array}$ & $\begin{array}{l}-0.113 \\
(-0.80) \\
\end{array}$ & $\begin{array}{l}0.387^{* *} \\
(2.41) \\
\end{array}$ & $\begin{array}{c}0.0612 \\
(0.36) \\
\end{array}$ \\
\hline Openness & $\begin{array}{c}0.0711 \\
(0.19)\end{array}$ & $\begin{array}{l}0.748^{*} \\
(1.80)\end{array}$ & $\begin{array}{l}-0.255 \\
(-0.57)\end{array}$ & $\begin{array}{l}0.878^{*} \\
(1.75)\end{array}$ \\
\hline Bank concentration & $\begin{array}{l}0.915 \\
(1.08)\end{array}$ & $\begin{array}{l}-0.127 \\
(-0.15) \\
\end{array}$ & $\begin{array}{l}1.839^{*} \\
(1.78)\end{array}$ & $\begin{array}{l}0.0551 \\
(0.06)\end{array}$ \\
\hline Industry age & $\begin{array}{l}0.482^{*} \\
(1.86)\end{array}$ & $\begin{array}{l}0.402^{*} \\
(1.99)\end{array}$ & $\begin{array}{l}0.257 \\
(0.75)\end{array}$ & $\begin{array}{l}0.128 \\
(0.55)\end{array}$ \\
\hline Common law & $\begin{array}{c}-0.0301 \\
(-0.09) \\
\end{array}$ & $\begin{array}{l}0.466 \\
(1.12) \\
\end{array}$ & $\begin{array}{l}-0.515 \\
(-1.33) \\
\end{array}$ & $\begin{array}{l}0.278 \\
(0.61) \\
\end{array}$ \\
\hline Fourth WVS wave (D) & $\begin{array}{l}0.509 \\
(1.63) \\
\end{array}$ & $\begin{array}{l}0.671^{* *} \\
(2.21) \\
\end{array}$ & $\begin{array}{l}0.349 \\
(0.92) \\
\end{array}$ & $\begin{array}{l}0.630^{*} \\
(1.80)\end{array}$ \\
\hline Fifth WVS wave (D) & $\begin{array}{l}-0.274 \\
(-0.77) \\
\end{array}$ & $\begin{array}{c}0.0877 \\
(0.23) \\
\end{array}$ & $\begin{array}{l}-0.411 \\
(-0.94) \\
\end{array}$ & $\begin{array}{l}0.226 \\
(0.47)\end{array}$ \\
\hline Constant & $\begin{array}{c}-8.660^{* * *} \\
(-3.59)\end{array}$ & $\begin{array}{l}-13.48^{* * *} \\
(-4.39)\end{array}$ & $\begin{array}{l}-9.120^{* * *} \\
(-2.90)\end{array}$ & $\begin{array}{c}-16.94^{* *} \\
(-4.14)\end{array}$ \\
\hline$N$ & 60 & 60 & 60 & 60 \\
\hline adj. $R^{2}$ & 0.695 & 0.733 & 0.769 & 0.824 \\
\hline Shapiro-Wilk W test (p-values) & 0.828 & 0.681 & 0.587 & 0.143 \\
\hline
\end{tabular}

Notes: Robust $t$ statistics in parentheses, ${ }^{*} p<0.10,{ }^{* *} p<0.05,{ }^{* * *} p<0.01$

The Shapiro-Wilk $W$ test is based on a null hypothesis that the population is normally distributed. 


\section{Conclusions}

Over the past few decades, the mutual fund industry around the world has developed significantly. However, the financial crisis in mid-2007 and the various financial scandals in recent years necessitate increasingly complex analyses of the capital markets and the mutual fund industry in particular. Socio-cultural variables such as trust, happiness, freedom of choice, or religious behaviour and values are generally ignored in explaining the development of this important industry in both developed and emerging countries. Acknowledging the unpublished paper by Keswani et al. (2014) dealing with the effects of culture on mutual fund management, ours is the first empirical study that analyses the determinants of the size of the mutual fund industry by taking into account socio-cultural variables. As distinct from other approaches that we reviewed in the initial sections, we use a particular set of cultural values that were proven to shape other financial processes, we draw on data provided by the World Values Survey (as opposed to the Hofstede/Schwartz framework employed by Keswani et al. [2014]), and we are able to use a dynamic set of values for the socio-cultural variables as provided by successive waves of the WVS.

First, we show that religiosity seems to play no significant role in explaining the differences in the evolution of the mutual fund industry. Also contrary to our theoretical expectations, we find no robust relationship between trust and the development of this industry. However, the effects of religiosity and trust could be reflected through other socio-cultural values such as the level of happiness. We also find support for the hypothesis that happiness is related to a high propensity to save and with investments with longterm horizons, and thus positively correlated with mutual fund industry development. The variable associated with individuals' perceptions of the freedom of choice and control over their lives has a positive impact on the size of this industry. As expected, individuals' preference for public ownership manifests a negative impact on development of the mutual fund industry. However, this relationship is no longer significant when we control for the level of economic development.

In order to test for the robustness of these results, control variables reflecting the banking, financial, and economic development are included in our analysis. A developed mutual fund industry is associated with greater stock market total value traded, with higher volumes of liquid liabilities in the economy, and with lower values for remittance inflows to GDP ratios. Moreover, we find a positive correlation between the age of a country's mutual fund industry and its size.

Our most general conclusion is that socio-cultural values matter. Although they can stimulate or inhibit the growth of the mutual fund industry, cultural factors are not iron cages for economic activity. Generally, if a country's policymakers intend to develop the capital market as a whole and, in particular, the mutual fund industry, we highlight that it is becoming increasingly important to understand and consider a large range of socio-cultural variables. However, our results must be carefully interpreted. Some questions remain, especially regarding the unexpected relations or the absence of significant correlations between the size of the mutual fund industry and some of our socio-cultural variables. These are suitable topics for further research. Subsequent studies could test the robustness of our results by employing other sources of data for the socio-cultural variables, using data from experimental surveys employed in the behavioural finance literature, or extending this analysis to other sectors of the capital market such as insurance and pension funds. 


\section{Appendix}

Socio-cultural Variables Based on World Values Survey (WVS) Questionnaires

\begin{tabular}{|l|l|l|}
\hline Variable Name & \multicolumn{1}{|c|}{ WvS question/statement } & \multicolumn{1}{|c|}{ Significance } \\
\hline Religious person & $\begin{array}{l}\text { Independently of whether you go to } \\
\text { church or not, would you say you are } \\
\text { 1. A religious person; 2. Not a religious } \\
\text { person; 3. A convinced atheist; } 4 \text {. Other } \\
\text { answer? }\end{array}$ & $\begin{array}{l}\text { Percentage of people declaring } \\
\text { themselves to be religious }\end{array}$ \\
\hline Trust & $\begin{array}{l}\text { Generally speaking, would you say that } \\
\text { most people can be trusted or that you } \\
\text { need to be very careful in dealing with } \\
\text { people? } \\
\text { Possible answers: 1. Most people can be } \\
\text { trusted; } 2 \text {. Can't be too careful }\end{array}$ & $\begin{array}{l}\text { Percentage of people responding } \\
\text { that most people can be trusted }\end{array}$ \\
\hline Happiness & $\begin{array}{l}\text { Taking all things together, would you say } \\
\text { you are: 1. Very happy; 2. Quite Happy; } 3 . \\
\text { Not very happy; 4. Not at all happy? }\end{array}$ & $\begin{array}{l}\text { Percentage of people declaring } \\
\text { themselves to be very happy } \\
\text { or quite happy }\end{array}$ \\
\hline Public ownership & $\begin{array}{l}\text { Private ownership of business should } \\
\text { be increased (Score 1) vs. Government } \\
\text { ownership of business should be increased } \\
\text { (Score 10) }\end{array}$ & Mean value \\
\hline Free choice & $\begin{array}{l}\text { Some people feel they have completely } \\
\text { free choice and control over their lives, } \\
\text { while other people feel that what they } \\
\text { do has no real effect on what happens to } \\
\text { them. Scaled between 1 (Not at all) to 10 } \\
\text { (A great deal) }\end{array}$ & Mean value \\
\hline
\end{tabular}

\section{References}

Bailey, W., Kumar, A., Ng, D. (2011). Behavioral Biases of Mutual Fund Investors. Journal of Financial Economics, 102(1), 1-27, http://dx.doi.org/10.1016/j.jineco.2011.05.002

Barro, R., Lee, J. W. (2013). A New Data Set of Educational Attainment in the World, 1950-2010. Journal of Development Economics, 104, 184-198, http://dx.doi.org/10.1016/j. jdeveco.2012.10.001

Beck, T., Demirgüç-Kunt, A., Levine, R. (2000). New Database on Financial Development and Structure. World Bank Economic Review, 14(3), 597-605, http://dx.doi.org/10.1093/ wber/14.3.597

Beugelsdijk, S., de Groot, H. L. F., van Schaik, A. B. T. M. (2004). Trust and Economic Growth: A Robustness Analysis. Oxford Economic Papers, 56(1), 118-134, http://dx.doi.org/10.1093/ oep/56.1.118

Brańas-Garza, P., Espín, A. M., Neuman, S. (2013). Effects of Religiosity on Social Behaviour: Experimental Evidence from a Representative Sample of Spaniards. Working Papers 2013-07, Bar-Ilan University, Department of Economics. 
Breuer, W., Quinten, B. (2009). Cultural Finance. Available at: http://papers.ssrn.com/sol3/papers. cfm?abstract_id $=1282068$

Brooks, A. C. (2003). Religious Faith and Charitable Giving. Policy Review, 121, 39-50.

Compton, W. C., Hoff man, E. (2012). Positive Psychology: The Science of Human Flourishing. 2nd Ed. Belmont: Wadsworth Publishing.

Djankov, S., La Porta, R., Lopez-de-Silanes, F., Shleifer, A. (2008). The Law and Economics of Self-Dealing. Journal of Financial Economics, 88(3), 430-465, http://dx.doi.org/10.1016/j. jfineco.2007.02.007

Easton, S. T., Walker, M. A. (1997). Income, Growth, and Economic Freedom. American Economic Review, 87(2), 328-332. Available at: http://www.jstor.org/stable/2950940

Ferreira, M. A., Keswani, A., Ramos, S., Miguel, A. F. (2013). The Determinants of Mutual Fund Performance: A Cross-Country Study. Review of Finance, 17(2), 483-525, http://dx.doi.org/10.1093/rof/rfs013

Frey, B., Stutzer, S. (2002). What Can Economists Learn from Happiness Research? Journal of Economic Literature, 40(2), 402-435, http://dx.doi.org/10.1257/jel.40.2.402

Guiso, L., Sapienza, P., Zingales, L. (2003). People's Opium? Religion and Economic Attitudes. Journal of Monetary Economics, 50(1), 225-282, http://dx.doi.org/10.1016/s03043932(02)00202-7

Guiso, L., Sapienza, P., Zingales, L. (2006). Does Culture Affect Economic Outcomes? Journal of Economic Perspectives, 20(2), 23-48, http://dx.doi.org/10.1257/jep.20.2.23

Guiso, L., Sapienza, P., Zingales, L. (2008). Trusting the Stock Market. Journal of Finance, 63(6), 2557-2600, http://dx.doi.org/10.1111/j.1540-6261.2008.01408.x

Guven, C. (2012). Reversing the Question: Does Happiness Affect Consumption and Savings

Behavior? Journal of Economic Psychology, 33(4), 701-717, http://dx.doi.org/10.1016/j. joep.2012.01.002

Helliwell, J. F., Layard, R., Sachs, J. D. (2013). World Happiness Report 2013. Available at: http://unsdsn.org/wp-content/uploads/2014/02/WorldHappinessReport2013_online.pdf

Hofstede, G. (1980). Culture's Consequences: International Differences in Work Related Values. Beverly Hills: CA, Sage.

Investment Company Institute (2012a). U.S. Households' Ownership of Mutual Funds. The Investment Company Institute Research Perspective, 18. Available at: http://www.ici. org/pdf/per18-06.pdf

Investment Company Institute (2012b). Characteristics of Mutual Fund Investors. The Investment Company Institute Research Perspective, 18. Available at: http://www.ici.org/pdf/per18-07.pdf

Investment Funds Institute of Canada (2012). Canadian Investors' Perceptions of Mutual Funds and the Mutual Fund Industry. Report prepared for the Investment Fund Institute of Canada by Pollara Inc. Available at: https://www.ifi c.ca/Content/Document. aspx?id=7344\&LangType=1033

Kaminsky, G., Lyons, R. K., Schmukler, S. L. (2004). Managers, Investors, and Crises: Mutual Fund Strategies in Emerging Markets. Journal of International Economics, 64(1), 113-134, http://dx.doi.org/10.1016/s0022-1996(03)00075-8

Keswani, A., Miguel, A. F., Ramos, S. B. (2014). Lazy Investors, Lazy Fund Managers, Lousy Performance: National Culture and Mutual Fund Management. Available at: http://www. rsm.nl/fi leadmin/home/Department_of_Finance_VG5_/PAM2014/Final_Papers/Aneel_ Keswani.pdf 
Khorana, A., Servaes, H., Tufano, P. (2005). Explaining the Size of the Mutual Fund Industry around the World. Journal of Financial Economics, 78(1), 145-185, http://dx.doi.org/10.1016/j. jineco.2004.08.006

Klapper, L., Sulla, V., Vittas, D. (2004). The Development of Mutual Funds around the World. Emerging Markets Review, 5(1), 1-38, http://dx.doi.org/10.1016/j.ememar.2003.12.001

Knack, S., Keefer, P. (1997). Does Social Capital Have an Economic Payoff? Quarterly Journal of Economics, 112(4), 1251-1273, http://dx.doi.org/10.1162/003355300555475

La Porta, R., Lopez-de-Silanes, F., Shleifer, A., Vishny, R. (1998). Law and Finance. Journal of Political Economy, 106(6), 1113-1155, http://dx.doi.org/10.1086/250042

Miller, A.S., Hoffmann, J.P. (1995). Risk and Religion: an Explanation of Gender Differences in Religiosity. Journal for the Scientific Study of Religion, 34(1), 63-75. http://dx.doi. org/10.2307/1386523

Mookerjee, R., Beron, K. (2005). Gender, Religion and Happiness. Journal of Behavioral and Experimental Economics, 34(5), 674-685, http://dx.doi.org/10.1016/j.socec.2005.07.012

Müller, S., Weber, M. (2010). Financial Literacy and Mutual Fund Investments: Who Buys Actively Managed Funds? Schmalenbach Business Review, 62(2), 125-153.

Peifer, J. L. (2011). Morality in the Financial Market? A Look at Religiously Affiliated Mutualb Funds in the USA. Socio-Economic Review, 9(2), 235-259, http://dx.doi.org/10.1093/ser/mwq024

Prasad, E. S., Rogoff, K., Wei, S. J., Kose, M. A. (2007). Financial Globalization, Growth and Volatility in Developing Countries, in Harrison, A., ed., Globalization and Poverty. Chicago, IL: University of Chicago Press, pp. 457-516.

Renneboog, L., Spaenjers, C. (2012). Religion, Economic Attitudes and Household Finance. Oxford Economic Papers, 64(1), 103-127, http://dx.doi.org/10.1093/oep/gpr025

Reuter, C. H. J. (2011). A Survey of 'Culture and Finance. Finance (Revue de l'Association Française de Finance), 32(1), 75-152. Available at: http://papers.ssrn.com/sol3/papers.cfm?abstract_ id $=1317324$

Sarracino, F. (2013). Determinants of Subjective Well-Being in High and Low Income Countries: Do Happiness Equations Differ Across Countries? Journal of Behavioral and Experimental Economics, 42(1), 51-66, http://dx.doi.org/10.1016/j.socec.2012.11.006

Sen, A. (1983). Poor, Relatively Speaking. Oxford Economic Papers, 35, 153-169.

Stiglitz, J., Sen, A., Fitoussi, J. (2009). Report by the Commission on the Measurement of Economic Performance and Social Progress. OFCE. Available at: http://www.stiglitz-sen-fi toussi.fr/en/ index.htm

Stojanov, R., Strielkowski, W. (2013). The Role of Remittances as More Efficient Tool of Development Aid in Developing Countries. Prague Economic Papers, 22(4), 487-503, http://dx.doi.org/10.18267/j.pep.464

Tingchi, L., Yu-Ying Huang, M., Zhu Zhenghao, C. (2007). Segment Variables of Chinese Mutual Fund Individual Investors. Investment Management and Financial Innovations, 4(4), 97-104. Availabe at: http://businessperspectives.org/journals_free/imfi/2007/imfi_en_2007_04_1_ Liu.pdf

Van Campenhout, G. (2007). Mutual Fund Selection Criteria and Determinants of Individual Fund Flows. Review of Business and Economics, XLII(4), 617-671.

Yartey, C.A. (2008). The Determinants of Stock Market Development in Emerging Economies: Is South Africa Different? IMF Working Paper, African Department, WP/08/32, 1-33.

Weber, M. (2005) [1930]. The Protestant Ethic and the Spirit of Capitalism. London and New York: Routledge Classics. 